\title{
Cell-free extracellular enzymatic activity is linked to seasonal temperature changes: a case study in the Baltic Sea
}

\author{
Federico Baltar ${ }^{1,2,3}$, Catherine Legrand ${ }^{1}$, and Jarone Pinhassi ${ }^{1}$ \\ ${ }^{1}$ Centre for Ecology and Evolution in Microbial Model Systems, Linnaeus University, Kalmar, Sweden \\ ${ }^{2}$ Department of Marine Science, University of Otago, Dunedin, New Zealand \\ ${ }^{3}$ NIWA/University of Otago Research Centre for Oceanography, Dunedin, New Zealand \\ Correspondence to: Federico Baltar (federico.baltar@otago.ac.nz)
}

Received: 14 December 2015 - Published in Biogeosciences Discuss.: 18 January 2016

Revised: 18 April 2016 - Accepted: 30 April 2016 - Published: 13 May 2016

\begin{abstract}
Extracellular enzymatic activities (EEAs) are a crucial step in the degradation of organic matter. Dissolved (cell-free) extracellular enzymes in seawater can make up a significant contribution of the bulk EEA. However, the factors controlling the proportion of dissolved EEA in the marine environment remain unknown. Here we studied the seasonal changes in the proportion of dissolved relative to total EEA (of alkaline phosphatase (APase), $\beta$-glucosidase (BGase), and leucine aminopeptidase (LAPase)), in the Baltic Sea for 18 months. The proportion of dissolved EEA ranged between 37 and 100, 0 and 100, and 34 and $100 \%$ for APase, BGase, and LAPase, respectively. A consistent seasonal pattern in the proportion of dissolved EEA was found among all the studied enzymes, with values up to $100 \%$ during winter and $<40 \%$ during summer. A significant negative relation was found between the proportion of dissolved EEA and temperature, indicating that temperature might be a critical factor controlling the proportion of dissolved relative to total EEA in marine environments. Our results suggest a strong decoupling of hydrolysis rates from microbial dynamics in cold waters. This implies that under cold conditions, cell-free enzymes can contribute to substrate availability at large distances from the producing cell, increasing the dissociation between the hydrolysis of organic compounds and the actual microbes producing the enzymes. This might also suggest a potential effect of global warming on the hydrolysis of organic matter via a reduction of the contribution of cell-free enzymes to the bulk hydrolytic activity.
\end{abstract}

\section{Introduction}

Prokaryotes play a central role in the marine biogeochemical cycles by transforming dissolved organic matter (DOM) into living particulate organic matter (Azam and Cho, 1987). These organisms preferentially consume high molecular weight DOM, as explained by the DOM size-reactivity model (Amon and Benner, 1996; Benner and Amon, 2015). However, since only molecules $<600 \mathrm{Da}$ can be directly transported across the prokaryotic cell membrane (Weiss et al., 1991), heterotrophic prokaryotes need to use extracellular enzymes (EEs) for hydrolyzing high molecular weight DOM into low molecular weight compounds suitable for uptake.

EEA in aquatic environments can be cell-associated (i.e. EEs attached to the cell wall or in the periplasmatic space), or dissolved (i.e. cell-free) in the surrounding waters (Hoppe et al., 2002). Until recently, most EEA in the marine environment was believed to be associated with cells (Hoppe, 1983; Hoppe et al., 2002) leading to the perception that only cellassociated EEs were of ecological significance (Chrost and Rai, 1993; Rego et al., 1985; Someville and Billen, 1983). However, other reports suggested a major contribution of dissolved EEA to the total oceanic EEA pool (Baltar et al., 2010; Baltar et al., 2013, 2010; Karner and Rassoulzadegan, 1995; Keith and Arnosti, 2001; Obayashi and Suzuki, 2008a). This high proportion of cell-free EEA is important because it can decouple hydrolysis rates of organic material from microbial dynamics. Thus, a high proportion of dissolved EEA could indicate a greater importance of the history of the water mass than of the actual processes occurring at the time of sampling (Arnosti, 2011; Baltar et al., 2010; Baltar et al., 2013; Karner and Rassoulzadegan, 1995). 
Potential sources of cell-free EEA include direct EE release from cells in response to appropriate substrate (Alderkamp et al., 2007), to bacterial starvation (Albertson et al., 1990), to changes in cell permeability (Chrost, 1991), to viral lysis (Karner and Rassoulzadegan, 1995), and to protist grazing (Bochdansky et al., 1995). However, little is known about what happens once the enzymes are free in the marine environment, including information about their lifetimes. The few available studies on the EE lifetime, indicate a lifetime range between tens and hundreds of hours. Surface water EE lifetimes, when incubated at in situ temperature, ranged between $>1$ and 9 days (Bochdansky et al., 1995; Steen and Arnosti, 2011; Ziervogel and Arnosti, 2008; Ziervogel et al., 2010). However, EE lifetimes of surface waters were longer (up to $40 \mathrm{~d}$ ) when incubated in the dark at $4{ }^{\circ} \mathrm{C}$ than at in situ conditions of light and temperature ( $\mathrm{Li}$ et al., 1998). This is consistent with the only available study comparing cold deep versus warm surface waters EE lifetimes, where EE lifetimes were about 1 order of magnitude longer in the deep waters (Baltar et al., 2013). These results suggest that temperature could be a critical factor preserving the activity of cell-free EEA and thereby controlling the proportion of dissolved EEA in the marine environment.

Despite the importance and implications of cell-free EEA in marine environments, little is known about the factors that control changes in the proportion of total EEA that is dissolved. To resolve this question, a long temporal sampling strategy that accounts for the long lifetime of EEs would be desirable, because this will include the strong seasonal changes, and because a field study will be more representative of what occurs in nature than experimental manipulations, particularly when looking at seasonal temporal scales. Here we studied the temporal changes in the proportion of dissolved relative to total EEA, in a continuous biweekly sampling with water from the Baltic Sea for 18 months. We aimed to reveal the seasonal variability of dissolved EEA and to decipher the factors that control the proportion of dissolved relative to total EEA (of glycolytic enzymes ( $\beta$-glucosidase, BGase), a proteolytic enzyme (leucine aminopeptidase, LAPase), and alkaline phosphatase (APase)). Based on previous research suggesting longer EE lifetimes in cold environments, we hypothesized that there would be a strong link between temperature and the proportion of dissolved relative to total EEA, with lower proportions of dissolved EEA during warm periods (e.g. summer) than during cold periods (e.g. winter). This hypothesis is based on the previous evidences of higher lifetimes of EEA in cold compared to warm waters (Baltar et al., 2010), suggesting that an overall low metabolic rate of microbes would favour higher percentages of dissolved EEA because the degradation of the enzymes (i.e. microbial heterotrophic activity) is reduced under lower temperatures.

\section{Materials and methods}

\subsection{Study site and sampling}

Seawater from the Baltic Sea proper was collected twice weekly for almost 18 months, from 22 March 2012 to the 15 August 2013. Samples were taken at $2 \mathrm{~m}$ depth at the Linnaeus Microbial Observatory (LMO) (N 56 $6^{\circ} 55.851$, E $17^{\circ}$ 03.640), $10 \mathrm{~km}$ off the east coast of Öland, Sweden, using a Ruttner sampler. Temperature was measured on-site by a thermometer placed in the Ruttner sampler, and the water was transported to the laboratory in acid-washed Milli-Qrinsed polycarbonate bottles within $1 \mathrm{~h}$.

\subsection{Biotic and abiotic environmental parameters}

Chlorophyll $a$ (Chl $a$ ) concentration was analysed following extraction using ethanol (Jespersen and Christoffersen, 1987). Chl $a$ concentration and dissolved inorganic nutrients $\left(\mathrm{NH}_{4}^{+}, \mathrm{NO}_{3}^{-}, \mathrm{PO}_{4}^{3-}\right.$, and $\left.\mathrm{SiO}_{2}\right)$ were analysed following previously described protocols (Jespersen and Christoffersen, 1987; Valderrama, 1981). Dissolved organic carbon (DOC) was measured via high-temperature catalytic oxidation using a TOC-V (total organic carbon analyzer) detector coupled to a TNM-1 unit (total nitrogen unit, Shimadzu Corporation) (Pages and Gadel, 1990). Bacterial abundance was determined using flow cytometry according to the protocol described in Del Giorgio et al. (1996). Bacterial heterotrophic production was derived from ${ }^{3} \mathrm{H}$-leucine incorporation rates measured on quadruplicates and two controls according to Smith and Azam (1992).

\subsection{Measurement of total and dissolved extracellular enzymatic activity (EEA)}

The hydrolysis of the fluorogenic substrate analogues 4-methylcoumarinyl-7-amide (MCA)-L-leucine-7-amido4-methylcoumarin, 4-methylumbelliferyl (MUF)- $\beta$-Dglucoside, and MUF-phosphate was analysed to estimate potential activity rates of leucine aminopeptidase (LAPase), $\beta$-glucosidase (BGase), and alkaline phosphatase (APase), respectively (Hoppe, 1983). The procedure was followed as previously described (Baltar et al., 2010, 2013, 2009). Briefly, EEA was determined after substrate addition and incubation using a spectrofluorometer with a microwell plate reader (FLUOstar - BMG Labtech) at excitation and emission wavelengths of 365 and $445 \mathrm{~nm}$, respectively. Samples $(300 \mu \mathrm{L})$ were incubated in the dark at in situ temperature for 1.5-3 h. Subsamples without substrate additions served as blanks to determine the background fluorescence of the samples. Previous experiments showed insignificant abiotic hydrolysis of the substrates (Azúa et al., 2003; Hoppe, 1993; Unanue et al., 1999). The fluorescence obtained at the beginning and the end of the incubation was corrected for the corresponding blank. The increase in fluorescence over time was transformed into hydrolysis activity using a standard 
curve established with different concentrations of the fluorochromes MUF and MCA added to $0.2 \mu \mathrm{m}$ filtered sample water. A final substrate concentration of $31.2 \mu \mathrm{mol} \mathrm{L}^{-1}$ was used to measure BGase activities, $100 \mu \mathrm{mol} \mathrm{L}^{-1}$ for APase, and $500 \mu \mathrm{mol} \mathrm{L}^{-1}$ for LAPase. These concentrations were previously determined as saturating substrate concentrations.

The total and the dissolved fraction of the EEA were distinguished as previously described (Baltar et al., 2010, 2013). Briefly, raw seawater was used for total EEA; whereas for dissolved EEA, samples were gently filtered through a low protein-binding $0.2 \mu \mathrm{m}$ Acrodisc ${ }^{\circledR}$ syringe filter (Pall) for dissolved EEA following the protocol of Kim et al. (2007). The use of low protein-binding filters is important in this context since the adsorption of extracellular enzymes depends on the type of the filter material used for size fractionation (Obayashi and Suzuki, 2008a). In the present study, dissolved (cell-free) EEA is defined as the EEA recovered in the filtrate. Total and dissolved EEA were determined on six replicate samples each.

\subsection{Statistical analyses}

The relations between variables were examined by means of correlation analysis computing Pearson pairwise statistics. Normality was checked with a Shapiro-Wilks test before Pearson correlations were calculated.

\section{Results and discussion}

A clear seasonal pattern in temperature was observed, with lower and relatively stable temperatures during winter (3$4^{\circ} \mathrm{C}$ ), and strong increases during spring-summer (up to $20^{\circ} \mathrm{C}$ ), followed by a quick temperature drop in autumn (Fig. 1a). Chlorophyll $a$ concentration varied between 0.4 and $4.8 \mu \mathrm{g} \mathrm{L}{ }^{-1}$, with maximum peaks during the two types of blooms that typically occur in the Baltic (Lindh et al., 2015), the diatom and dinoflagellate spring bloom (April-May), and the cyanobacterial summer bloom (July-September) (Legrand et al., 2015) (Fig. 1b).

The total (bulk) EEA of APase, LAPase, and BGase followed a similar temporal pattern (Fig. 2a). APase was the EEA with the highest rates (ranging from 0 to $32 \mathrm{nmol} \mathrm{L}^{-1} \mathrm{~h}^{-1}$ ), followed by LAPase (from 0.6 to $9.3 \mathrm{nmol} \mathrm{L}^{-1} \mathrm{~h}^{-1}$ ) and BGase (from 0.1 to $\left.21 \mathrm{nmol} \mathrm{L}^{-1} \mathrm{~h}^{-1}\right)$, indicating a potential significant $\mathrm{P}$ limitation in the Baltic Sea (Granéli et al., 1990; Hagström et al., 2001). The strongest peaks in BGase and LAPase co-occurred (June and August 2012, May and August 2013), and these enzymes were significantly correlated (Pearson's $r=0.49, p=0.024)$. These peaks in BGase and LPase coincided with some of the APase and the Chla $a$ peaks, suggesting a potential link between these different enzymes and the phytoplankton dynamics. APase was significantly correlated to BGase (Pearson's $r=0.53, \quad p=0.013$ )
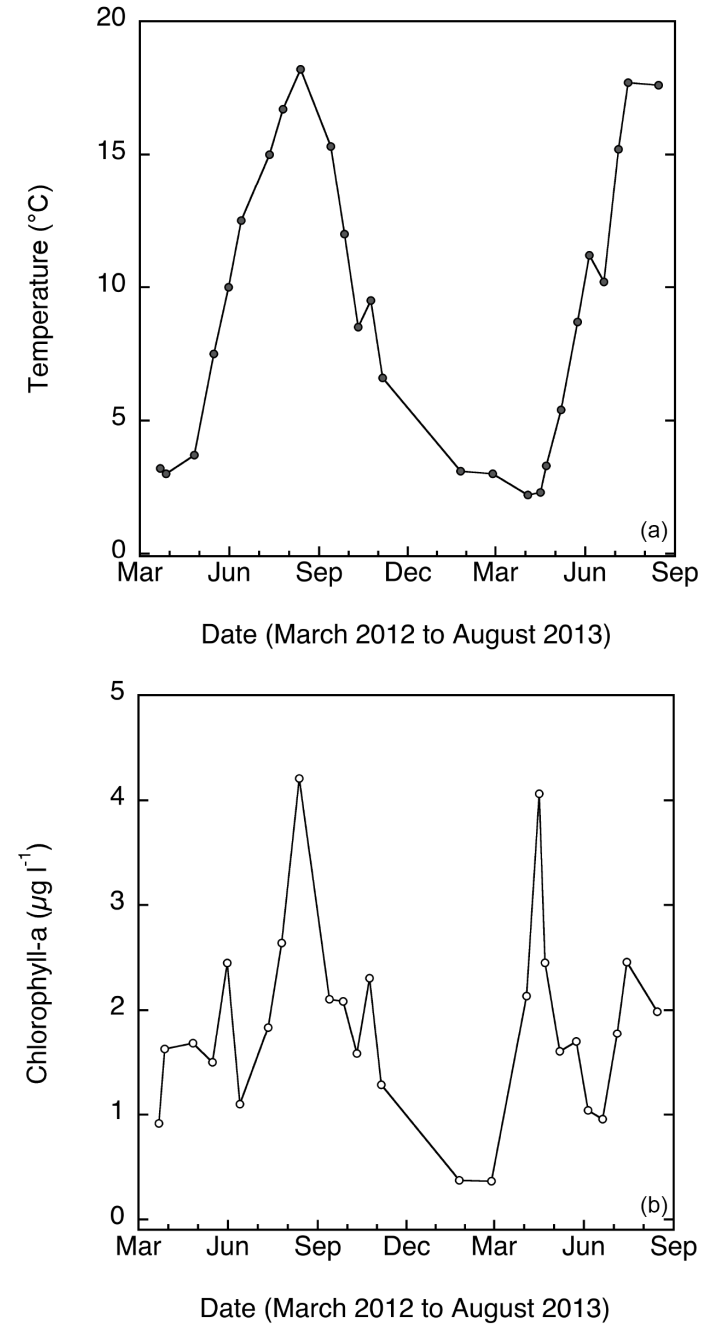

Figure 1. Temporal dynamics in (a) temperature and (b) chlorophyll $a$ concentrations, at the Linnaeus Microbial Observatory (LMO, Baltic Sea) from March 2012 to August 2013.

but not to LAPase (Pearson's $r=0.20, p=0.346$ ). The BGase : LAPase ratio, which has been generally suggested to be indicative of the relative degradation of polysaccharides relative to proteinaceous material, peaked when the highest BGase and LAPase rates were observed (May-June and August-October), just following the diatom/dinoflagellate spring bloom (April-May) and the cyanobacterial summer blooms (July-September). This is agreement with the results obtained in a recent seasonal study in the Adriatic Sea, where BGase prevailed over LAPase associated with phytoplankton blooms (Celussi and Del Negro, 2012). Nevertheless, results from other reports question the validity of the BGase:LPase ratio as an indicator of the relative degradation of polysaccharides relative to proteins. Previous investigations of a range of peptidases substrates (Bong et al., 2013; Obayashi and Suzuki, 2008b, 2005) have shown that LAPase activity levels vary in a manner not indicative 



Figure 2. Temporal dynamics in (a) extracellular enzymatic activities of alkaline phosphatase (APase), $\beta$-glucosidase (BGase), and leucine aminopeptidase (LAPase), and (b) the BGase : LAPase ratio, at the Linnaeus Microbial Observatory (LMO, Baltic Sea) from March 2012 to August 2013.

of other peptidase activities, and a recent report suggested that LAPase should not be interpreted as a quantitative proxy of the total peptidolytic potential of the community (Steen et al., 2015). Furthermore, measurements of BGase do not represent a complete picture of the broad and variable spectrum of polysaccharide hydrolases present in the ocean (Arnosti, 2011). There was a tendency for higher EEA rates (and BGase:LAPase ratio) in 2013 as compared to 2012 , likely explained by the reported interannual variability of phytoplankton communities linked to environmental conditions in the Baltic Sea (Kahru and Elmgren, 2014; Legrand et al., 2015), since different phytoplankton groups can release diverse types of organic carbon compounds, which would likely select for different bacterioplankton groups/enzymes (Arrieta and Herndl, 2002; Pinhassi et al., 2004).

The proportion of dissolved relative to total EEA ranged between 0 and $100 \%$, where LAPase and APase showed a similar range (37-100 and $37-100 \%$, respectively) and

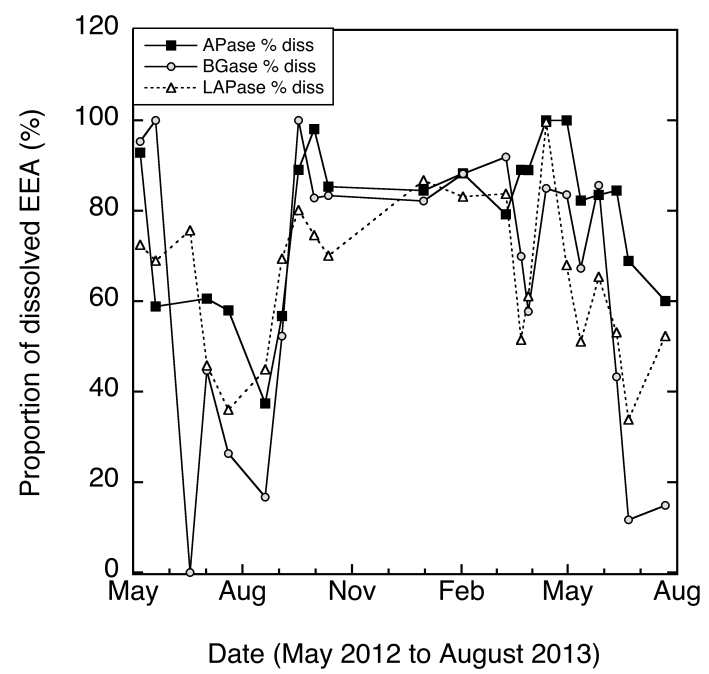

Figure 3. Temporal dynamics in the proportion of dissolved relative to total extracellular enzymatic activities (EEA) of alkaline phosphatase (APase), $\beta$-glucosidase (BGase), and leucine aminopeptidase (LAPase), at the Linnaeus Microbial Observatory (LMO, Baltic Sea) from May 2012 to August 2013.

BGase showed the broadest range (0-100\%) (Fig. 3). LAPase was the EEA with the lowest seasonal amplitude variability in the proportion of dissolved EEA, whereas BGase showed the largest seasonal variability. These values are within the same ranges reported in the surface coastal North Sea waters (Someville and Billen, 1983), Tokyo Bay (Hashimoto et al., 1985), Mediterranean Sea (Karner and Rassoulzadegan, 1995), Elbe estuary (Karrasch et al., 2003), Gulf of Mexico (Ziervogel and Arnosti, 2008; Ziervogel et al., 2010), North Pacific Subtropical Gyre (Duhamel et al., 2010), and the epipelagic to bathypelagic waters of the Atlantic (Baltar et al., 2010, 2013).

The proportion of dissolved EEA showed a clear seasonal pattern in our study (despite the great variability in the bulk EEA rates), with higher values in winter and a pronounced decrease in summer. Superimposed on this seasonal pattern, there were occasionally stronger fluctuations in the proportion of dissolved EEA (Fig. 3). This coincides with the phytoplankton bloom as indicated by the increases in Chl $a$ concentration (Fig. 1b) and in APase (Fig. 2a), which is consistent with the rapid succession in different phytoplankton (and bacterioplankton) taxa during those months at this study site (Lindh et al., 2015).

This overall seasonal pattern in the percentage of dissolved EEA was conserved among all the enzymes studied (APase, BGase, and LAPase), suggesting that the main factors regulating the proportion of dissolved EEA affect all enzymes equally, irrespectively of their metabolic function. This advocates for some environmental factor rather than a biological factor controlling the proportion of dissolved EEA. The most logical factor that could be responsible for this seasonal 
Table 1. Pearson's correlation coefficient $(r)$ between proportion of dissolved extracellular enzymatic activities (alkaline phosphatase (APase), $\beta$-glucosidase (BGase), and leucine aminopeptidase (LAPase)) and Chlorophyll $a$, salinity, inorganic nutrients, dissolved organic carbon (DOC), bacterial abundance (BA), and bacterial heterotrophic production (BP). Values of $r$ that are significant at $p<0.05$ are highlighted in bold.

\begin{tabular}{|c|c|c|c|c|c|c|}
\hline & \multicolumn{2}{|c|}{$\%$ APase } & \multicolumn{2}{|c|}{$\%$ BGase } & \multicolumn{2}{|c|}{$\%$ LAPase } \\
\hline & $r$ & $p$ value & $r$ & $p$ value & $r$ & $p$ value \\
\hline Temp & -0.60 & 0.004 & -0.73 & 0.001 & -0.68 & 0.001 \\
\hline Chlorophyll $a$ & -0.16 & 0.499 & -0.43 & 0.052 & -0.57 & 0.006 \\
\hline Salinity & -0.22 & 0.330 & 0.18 & 0.443 & 0.42 & 0.059 \\
\hline Nitrate & 0.21 & 0.372 & 0.34 & 0.132 & 0.46 & 0.034 \\
\hline Phosphate & 0.38 & 0.088 & 0.47 & 0.030 & 0.51 & 0.017 \\
\hline Silicate & 0.27 & 0.243 & 0.20 & 0.379 & 0.24 & 0.288 \\
\hline Ammonium & 0.03 & 0.892 & -0.07 & 0.758 & -0.04 & 0.862 \\
\hline DOC & -0.18 & 0.433 & -0.66 & 0.001 & -0.65 & 0.001 \\
\hline BA & -0.32 & 0.157 & -0.39 & 0.077 & -0.16 & 0.500 \\
\hline BP & -0.38 & 0.092 & -0.64 & 0.002 & -0.63 & 0.002 \\
\hline
\end{tabular}

pattern would be solar radiation and/or temperature. Inactivation of extracellular enzymes by photochemical reactions has been found in biofilm microbiota (Espeland and Wetzel, 2001). However, in laboratory experiments with Arctic surface waters, the activity of cell-free EEs (APase and LAPase) was not affected by light (under full spectrum natural sunlight), suggesting that photochemical reactions are not relevant pathway for the decay of cell-free EE in seawater (Steen and Arnosti, 2011). Indeed, we found that only temperature was significantly correlated to the proportion of dissolved EEA of the three enzymes studied (APase (Pearson's $r=-0.60, p=0.0035)$ ), BGase (Pearson's $r=-0.73, p=$ 0.0002), and LAPase (Pearson's $r=-0.68, p=0.0006)$ ) (Table 1). This strong correlation between temperature and the proportion of dissolved EEA was always negative, suggesting that lower temperatures favour the proportion of cellfree EEA. These results are consistent with the negative effect of temperature on EE lifetimes found in an incubation experiment with Red Sea surface water (Li et al., 1998), the extended lifetime of cell-free EE in Arctic waters (Steen and Arnosti, 2011), and with the EE lifetimes 1 order of magnitude higher found in the deep as compared to the surface waters in the Atlantic (Baltar et al., 2013). This suggests that low temperature preserves the constitutive activity of the cell-free enzymes better (than warm temperature), allowing them to remain active for longer periods. This might be linked to a reduction in the metabolism of heterotrophic microbes that would reduce the consumption/degradation rates of dissolved EEs. This hypothesis is supported by the significant negative correlations found between the proportion of dissolved BGase and LAPase and the bacterial heterotrophic production and DOC concentration (Table 1), which suggests that the proportion of dissolved EEA (BGase and LAPase) is higher when the microbial heterotrophic degrading activities are lower (during winter). This decreased heterotrophic activity would facilitate the preservation or accumulation of dissolved EEA. The higher proportion of dissolved EEA during winter suggests that the decoupling of in situ hydrolysis rates from actual microbial dynamics is stronger during winter (or in cold waters). Thus, these results underpin the importance of considering this stronger cold-related decoupling when relating EEA to other microbial processes. These results also suggest that under the projected global warming scenario, the hydrolysis of organic matter by cell-free EE might be reduced due to a shorter lifetime of the EEs.

\section{Conclusions}

Overall, the results of this study suggest that a relevant fraction of the total EEA measured in a particular environment can be due to free EEs, which might be a consequence of the substrate history of the water masses. Thus, advection of dissolved EEA might be a critical source of EEA in any given environment (Baltar et al., 2010, 2013; Steen and Arnosti, 2011). Other factors might also allow for extended EE lifetimes during advection, like association of EEs to particles (Gianfreda and Scarfi, 1991; Naidja et al., 2000; Ziervogel et al., 2007), to exopolymeric matrix (Decho, 1990), and to detrital particle complexes (Nagata and Kirchman, 1992). Low temperature seems to be a critical factor favouring longer EE lifetimes and thereby higher proportions of dissolved relative to total EEA. This implies that under low temperature conditions, cell-free enzymes can contribute to substrate availability at large distances from the producing cell, increasing the disconnection between the hydrolysis of organic compounds and the actual microbes producing the enzymes. Moreover, under warmer conditions, like those predicted to occur due to global warming, the hydrolysis of organic matter (i.e. the rate-limiting step in the degradation of organic matter) can 
be reduced due to a lower contribution of the cell-free EE hydrolysis.

Acknowledgements. We acknowledge Anders Månsson, Emil Fridolfsson, Kristofer Bergström, Saraladevi Muthusamy, Markus Lindh, Mireia Bertos Fortis, and Oscar Nordahl for their neverending energy to carry out field sampling and Sabina Arnautovic and Emmelie Nilsson for their skillful technical assistance in the processing of samples. This research was supported by grants from the European Science Foundation EuroEEFG project MOCA and The Swedish Research Council (VR) to J. Pinhassi, and the Strategic Marine Environmental Research program ECOCHANGE funded by the Swedish Research Council (Formas) to J. Pinhassi and C. Legrand. F. Baltar was supported by a University of Otago Research Grant. We would like to acknowledge the support and insightful comments of the reviewers and the Associate Editor (Gerhard Herndl), which clearly helped improve the overall merit of the manuscript.

Edited by: G. Herndl

\section{References}

Albertson, N. H., Nystrom, T., and Kjelleberg, S.: Macromolecularsynthesis during recovery of the marine Vibrio sp. S14 from starvation, J. Gen. Microbiol., 136, 2201-2207, 1990.

Alderkamp, A. C., Rijssel, M. V., and Bolhuis, H.: Characterization of marine bacteria and the activity of their enzyme systems involved in degradation of the algal storage glucan laminarin, FEMS Microbiol. Ecol., 59, 108-117, 2007.

Amon, R. M. W. and Benner, R.: Bacterial utilization of different size classes of dissolved organic matter, Limnol. Oceanogr., 41, 41-51, 1996.

Arnosti, C.: Microbial extracellular enzymes and the marine carbon cycle, Annual Review of Marine Science, 3, 401-425, 2011.

Arrieta, J. M. and Herndl, G. J.: Changes in bacterial betaglucosidase diversity during a coastal phytoplankton bloom., Limnol. Oceanogr., 47, 594-599, 2002.

Azam, F. and Cho, B. C.: Bacterial utilization of organic matter in the sea, in: Ecology of microbial communities, Cambridge University Press, Cambridge, 1987.

Azúa, I., Uanue, M., Ayo, B., Arrtolozaga, I., Arrieta, J. M., and Iriberri, J.: Influence of organic matter quality in the cleavage of polymers by marine bacterial communities, J. Plankton Res., 25, 1451-1460, 2003.

Baltar, F., Sintes, E., Van Aken, H., Gasol, J. M., Arístegui, J., and Herndl, G. J.: Prokaryotic extracellular enzymatic activity in relation to biomass production and respiration in the meso- and bathypelagic waters of the (sub)tropical Atlantic, Environ. Microbiol., 11, 1998-2014, 2009.

Baltar, F., Arístegui, J., Gasol, J. M., Sintes, E., Aken, H. M. V., and Herndl, G. J.: High dissolved extracellular enzymatic activity in the deep central Atlantic Ocean, Aquat. Microb. Ecol., 58, 287302, 2010 .

Baltar, F., Arístegui, J., Gasol, J. M., Yokokawa, T., and Herndl, G. J.: Bacterial Versus Archaeal Origin of Extracellular Enzymatic Activity in the Northeast Atlantic Deep Waters, Microb. Ecol., 65, 277-288, 2013.
Benner, R. and Amon, R. M.: The size-reactivity continuum of major bioelements in the ocean, Annual Review of Marine Science, 7, 185-205, 2015.

Bochdansky, A. B., Puskaric, S., and Herndl, G. J.: Influence of zooplankton grazing on free dissolved enzymes in the sea, Mar. Ecol. Prog. Ser., 121, 53-63, 1995.

Bong, C. W., Obayashi, Y., and Suzuki, S.: Succession of protease activity in seawater and bacterial isolates during starvation in a mesocosm experiment, Aquat. Microb. Ecol., 69, 33-46, 2013.

Celussi, M. and Del Negro, P.: Microbial degradation at a shallow coastal site: Long-term spectra and rates of exoenzymatic activities in the NE Adriatic Sea, Estuarine, Coastal and Shelf Science, 115, 75-86, 2012.

Chrost, R. J.: Environmental control of the synthesis and activity of aquatic microbial ectoenzymes, in: Microbial enzymes in aquatic environments, Brock/Springer series on contemprorary bioscience, Springer Verlag, New York, 1991.

Chrost, R. J. and Rai, H.: Ectoenzyme activity and bacterial secondary production in nutrient-improverished and nutrientenriched mesocosms, Microb. Ecol., 25, 131-150, 1993.

Decho, A. W.: Microbial exopolymers secretions in ocean environments: their role(s) in food webs and marine processes, Oceanogr. Mar. Biol., 28, 73-153, 1990.

Del Giorgio, P. A., Bird, D. F., Prairie, Y. T., and Planas, D.: Flow cytometric determination of bacterial abundance in lake plankton with the green nucleid acid stain SYTO 13, Limnol. Oceanogr., 41, 783-789, 1996.

Duhamel, S., Dyhrman, S. T., and Karl, D. M.: Alkaline phosphatase activity and regulation in the North Pacific Subtropical Gyre, Limnol. Oceanogr., 55, 1414-1425, 2010.

Espeland, E. and Wetzel, R.: Complexation, stabilization, and UV photolysis of extracellular and surface-bound glucosidase and alkaline phosphatase: implications for biofilm microbiota, Microb. Ecol,, 42, 572-585, 2001.

Gianfreda, L. and Scarfi, M. R.: Enzyme stabilization: state of the art, Mol. Cell. Biochem., 100, 97-128, 1991.

Granéli, E., Wallström, K., Larsson, U., Granéli, W., and Elmgren, R.: Nutrient limitation of primary production in Baltic Sea area, Ambio, 19, 142-151, 1990.

Hagström, Å., Azam, F., Kuparinen, J., and Zweifel, U.-L.: Pelagic plankton growth and resource limitations in the Baltic Sea, in: A systems analysis of the Baltic Sea, Springer-Verlag, 2001.

Hashimoto, S., Fujiwara, K., Fuwa, K., and Saino, T.: Distribution and characteristics of carboxypeptidase activity in pond, river, and seawater in the vicinity of Tokyo, Limnol. Oceanogr., 30, 631-645, 1985.

Hoppe, H.-G.: Significance of exoenzymatic activities in the ecology of brackish water: measurements by means of methylumbelliferyl-substrates, Mar. Ecol. Prog. Ser., 11, 299308, 1983.

Hoppe, H. G.: Use of fluorogenic model substrates for extracellular enzyme activity (EEA) measurement of bacteria, in: Handbook of methods in aquatic microbial ecology, edited by: Kemp P. F., Sherr, B. F., Sherr, E. B., and Cole, J. J., Lewis Publishers, Boca Raton, 423-431, 1993.

Hoppe, H.-G., Arnosti, C., and Herndl, G. J.: Ecological significance of bacterial enzymes in the marine environment, in: Enzymes in the environment: activity, ecology, and applications, 
edited by: Burns, R. G. and Dick, R. P., Marcel Dekker, Inc., New York, 2002.

Jespersen, A.-M. and Christoffersen, K.: Measurements of chlorophyll a from phytoplankton using ethanol as extraction solvent, Arch. Hydrobiol., 109, 445-454, 1987.

Kahru, M. and Elmgren, R.: Multidecadal time series of satellitedetected accumulations of cyanobacteria in the Baltic Sea, Biogeosciences, 11, 3619-3633, doi:10.5194/bg-11-3619-2014, 2014.

Karner, M. and Rassoulzadegan, F.: Extracellular enzyme activity: indications for high short-term variability in a coastal marine ecosystem, Microb. Ecol., 30, 143-156, 1995.

Karrasch, B., Ullrich, S., Mehrens, M., and Zimmermann-Timm, H.: Free and particle-associated extracellular enzyme activity and bacterial production in the lower Elbe estuary, Germany, Acta. Hydroch. Hydrob., 31, 297-306, 2003.

Keith, S. C. and Arnosti, C.: Extracellular enzyme activity in a riverbay-shelf transect: variations in polysaccharide hydrolysis rates with substrate and size class, Aquat. Microb. Ecol., 24, 243-253, 2001

Kim, C., Nishimura, Y., and Nagata, T.: High potential activity of alkaline phosphatase in the benthic nepheloid layer of a large mesotrophic lake: implications for phosphorus regeneration in oxygenated hypolimnion, Aquat. Microb. Ecol., 49, 303-311, 2007

Legrand, C., Fridolfsson, E., Bertos-Fortis, M., Lindehoff, E., Larsson, P., Pinhassi, J., and Andersson, A.: Interannual variability of phyto-bacterioplankton biomass and production in coastal and offshore waters of the Baltic Sea, Ambio, 44, 427-438, 2015.

Li, H., Veldhuis, M. J. W., and Post, A. F.: Alkaline phosphatase activities among planktonic communities in the northern Red Sea, Mar. Ecol. Prog. Ser., 173, 107-115, 1998.

Lindh, M. V., Sjöstedt, J., Andersson, A. F., Baltar, F., Hugerth, L. W., Lundin, D., Muthusamy, S., Legrand, C., and Pinhassi, J.: Disentangling seasonal bacterioplankton population dynamics by high-frequency sampling, Environ. Microbiol., 17, 2459 2476, 2015.

Nagata, T. and Kirchman, D. L.: Release of macromolecular organic complexes by heterotrophic marine flagellates, Mar. Ecol. Prog. Ser., 83, 233-240, 1992.

Naidja, A., Huang, P. M., and Bollag, J. M.: Enzyme-clay interactions and their impact on transformations of natural and anthropogenic organic compounds in soil, J. Environ. Qual., 29, 677691, 2000

Obayashi, Y. and Suzuki, S.: Proteolytic enzymes in coastal surface seawater: significant activity of endopeptidases and exopeptidases, Limnol. Oceanogr., 50, 722-726, 2005.

Obayashi, Y. and Suzuki, S.: Adsorption of extracellular proteases in seawater onto filters during size fractionation, J. Oceanogr., 64, 367-372, 2008a.
Obayashi, Y. and Suzuki, S.: Occurrence of exo-and endopeptidases in dissolved and particulate fractions of coastal seawater, Aquat. Microb. Ecol., 50, 231-237, 2008b.

Pages, J. and Gadel, F.: Dissolved organic matter and UV absorption in a tropical hyperhaline estuary, Sci. Total Environ., 99, 173204, 1990.

Pinhassi, J., Sala, M. M., Havskum, H., Peters, F., Guadayol, O., Malits, A., and Marrasé, C.: Changes in bacterioplankton composition under different phytoplankton regimens, Appl. Environ. Microbiol., 70, 6753-6766, 2004.

Rego, J. V., Billen, G., Fontigny, A., and Someville, M.: Free and attached proteolytic activity in water environments, Mar. Ecol. Prog. Ser., 21, 245-249, 1985.

Smith, D. C. and Azam, F.: A simple, economical method for measuring bacterial protein synthesis rates in seawater using ${ }^{3} \mathrm{H}-$ leucine, Marine Microbial Food Webs, 6, 107-114, 1992.

Someville, M. and Billen, G.: A method for determining exoproteolytic activity in natural waters, Limnol. Oceanogr., 28, 190-193, 1983.

Steen, A. D. and Arnosti, C.: Long lifetimes of beta-glucosidase, leucine aminopeptidase, and phosphatase in Arctic seawater, Mar. Chem., 123, 127-132, 2011.

Steen, A. D., Vazin, J. P., Hagen, S. M., Mulligan, K. H., and Wilhelm, S. W.: Substrate specificity of aquatic extracellular peptidases assessed by competitive inhibition assays using synthetic substrates, Aquat. Microb. Ecol., 75, 271-281, 2015.

Unanue, M., Ayo, B., Agis, M., Slezak, D., Herndl, G. J., and Iriberri, J.: Ectoenzymatic activity and uptake of monomers in marine bacterioplankton described by a biphasic kinetic model, Microb. Ecol., 37, 36-48, 1999.

Valderrama, J.: The simultaneous analysis of total nitrogen and total phosphorus in natural waters, Mar. Chem., 10, 109-122, 1981.

Weiss, M., Abele, U., Weckesser, J., Welte, W., Schiltz, E., and Schulz, G. E.: Molecular architecture and electrostatic properties of bacterial porin, Science, 254, 1627-1630, 1991.

Ziervogel, K. and Arnosti, C.: Polysaccharide hydrolysis in aggregates and free enzyme activity in aggregate-free seawater from the north-eastern Gulf of Mexico, Environ. Microbiol., 10, 289299, 2008.

Ziervogel, K., Karlsson, E., and Arnosti, C.: Surface associations of enzymes and of organic matter: consequences for hydrolytic activity and organic matter remineralization in marinne systems, Mar. Chem., 104, 241-252, 2007.

Ziervogel, K., Steen, A. D., and Arnosti, C.: Changes in the spectrum and rates of extracellular enzyme activities in seawater following aggregate formation, Biogeosciences, 7, 1007-1015, doi:10.5194/bg-7-1007-2010, 2010. 